\title{
Inhibitory Effects of Cyanide on the Activity of Granular Starch Hydrolyzing Enzyme (GSHE) during Hydrolysis of Cassava (Manihot Esculenta Crantz) Starch
}

\author{
Hargono Hargono ${ }^{1 *}$, Andri Cahyo Kumoro, Bakti Jos \\ 1 Department of Chemical Engineering, Faculty of Engineering, Diponegoro University, Prof. H. Soedarto, \\ SH Road-Semarang, Indonesia \\ ${ }^{*}$ Corresponding author, email: andrewkomoro@che.undip.ac.id
}

Received: 26 January 2018, Accepted: 07 May 2018, Published online: 16 May 2018

\begin{abstract}
The kinetics and inhibitory effects of cyanide on the granular starch hydrolyzing enzyme (GSHE) activity during hydrolysis of cassava (Manihot esculenta Crantz) starch at low temperature were studied. The substrates included native cassava starch at various concentrations (100-400 g/L) and native cassava starches with added cyanide at various concentrations (50-150 mg/kg), while the concentration of enzyme was $1.5 \%(\mathrm{w} / \mathrm{w})$. A decrease in reducing sugar concentration during hydrolysis of cassava starch indicated that the cyanide reduced the enzyme activity. Lineweaver-Burk plot of Michaelis-Menten equation was used to study the inhibition kinetics. The maximum velocity $\left(V_{\max }\right)$ value was higher for native cassava starch than that of native cassava starch with added cyanides. The presence of cyanide was found to reduce the $V_{\text {max }}$ values. No significant different of the saturation constant $\left(K_{m}\right)$ value between native cassava starch and native cassava starch with added cyanides was observed. Based on the inhibition type analysis, the effect of cyanide in the cassava starch can be classified as a noncompetitive inhibition, with the $K_{i}$ value of $0.33 \mathrm{mg} / \mathrm{L}$.
\end{abstract}

Keywords

cyanides, inhibitory, enzyme activity, kinetics, hydrolysis

\section{Introduction}

Cassava is a high-yielding crop that can grow well in the tropical and subtropical regions, such Africa, South America, India and Southeast Asia. Indonesia is one of the cassava leading producers in the world. Cassava has many superior growing characteristics over the other crops that include high drought and flood-tolerance and ability to grow on light sandy soils and medium texture soils [1]. Another advantage of cassava is related to its higher starch content than many other stem tuber plants. The conversion of cassava starch into reducing sugar is expected to increase its economic potentials, especially applied to bitter cassava. Cassava starch can be converted into glucose syrup (for food applications) and to ethanol (for fuel application) through hydrolysis and fermentation processes. Based on its starch content, it is estimated that 7.2 tons of fresh cassava can produce 1.9570 ton of glucose or 1 ton of ethanol [2].

Cassava plant produces two cyanogenic glucosides (CG), namely linamarin and a small portion of lotaustralin [3]. Linamarin produces the toxic hydrogen cyanide compound, which can be hazardous to consumers [4]. Based on the CG content, cassava can be classified into high cyanide (bitter) and low cyanide (sweet) cassavas [5]. Lambri et al. [6] reported that the total cyanide content of sweet white and bitter white cassava roots were 374 and $442 \mathrm{mg} /$ kg (d.w.), respectively. Earlier, Djazuli and Bradbury [7] found the cyanogen content of cassava starch in Indonesia to be around $12 \mathrm{mg} / \mathrm{kg}$ (d.w.). Recently, Hargono et al. [8] investigated the effect of cyanide on hydrolysis of sweet cassava and bitter cassava starches using granular starch hydrolyzing enzyme (GSHE). It was observed that cyanide was an inhibitor for the enzyme. Tung et al. [9] studied the effect of the presence of $20 \mathrm{mg} / \mathrm{L}$ cyanide on the fermentation of cassava starch using Aspergillus oryzae IFO 30113 strains for 2-12 days. The cyanide was found to cause a decrease of both biomass and glucose concentration. Cyanide also decreased the catalase (CAT) enzyme activity $(5.27 \%$ and $6.61 \%)$ in the brain tissues of the fish exposed to $0.5 \mathrm{mg} / \mathrm{L}$ concentration of cyanide for 24 and $72 \mathrm{~h}$, respectively [10]. Several authors had investigated 
the enzymatic hydrolysis of numerous tuber starches. These studies included the hydrolysis profiles of native and mildly heat-treated tapioca and sweet potato starches at sub gelatinization temperature [11], direct conversion of cassava and sweet potato roots slurry into glucose and high fructose syrups [12], and the production of glucose and high fructose syrup from various tuber starches [13]. The hydrolyzed starches were chemically analyzed for their degree of hydrolysis, which was also further physically proven by the presence of distinct pores penetrating deep into the starch granules [14]. However, the effect of cyanide that probably contained in the starch on the enzyme activity was not studied. The Michaelis-Menten equation provides an easy way of determining whether an enzyme inhibitor is either competitive, noncompetitive or uncompetitve [15].

The objectives of this study are to investigate the inhibition mechanism of GSHE activity by cyanide during hydrolysis of cassava (Manihot esculenta Crantz) starch and to obtain the kinetics parameters. The competitive, noncompetitive and uncompetitive inhibition kinetics models were used to quantify the inhibitory effect of this cyanogenic compound. The model parameters $\left(K_{m}\right.$ and $V_{\max }$ ) obtained from this study is expected to be used for the scale up of the hydrolysis process into pilot plant or even the commercial scale.

\section{Materials and Methods}

\subsection{Materials}

Ten months age of cassava (Manihot esculenta Crantz) tubers were obtained from commercial farm located in Wonogiri district in Indonesia. The extraction procedure, cyanide content and physicochemical properties of the cassava used in this study were the same as those used in the previous research conducted by Hargono [8]. Cyanide (as Potassium cyanide) was the product of MERCK, potassium sodium tartrate tetrahydrate and 3,5-Dinitrosalicylic acid, sodium hydroxide ( $98 \%$, Merck), sodium sulfite (98.5\%, Merck), sulfuric acid (98.5\%, Merck), sodium acetate buffer, glucose $(99.5 \%)$, were purchased from their authorized distributor. Granular starch hydrolyzing enzyme as Stargen ${ }^{\mathrm{TM}}$ 002, contains Aspergillus kawachi alpha-amylase expressed in Trichoderma reese $i$ and a glucoamylase from Trichoderma reesei that work synergistically to hydrolyze granular starch substrate to glucose was produced by Genencor (Palo Alto, USA). The activity and optimal $\mathrm{pH}$ range declared by the producer are $570 \mathrm{GAU} / \mathrm{g}$ and 4.0-4.5, respectively [16].

\subsection{Enzymatic Hydrolysis}

Cassava starch slurry of 100, 150, 200, 250, 300, 350 and $400 \mathrm{~g} / \mathrm{L}$ concentration were used in this research. The slurry was adjusted to $\mathrm{pH} 4$ by addition of $50 \mathrm{mM}$ sodium acetate buffer. Then, the Stargen ${ }^{\mathrm{TM}} 002$ enzyme was gently added to the slurry at $1.5 \% \mathrm{w} / \mathrm{w}$ concentration. The mixture was incubated at $80 \pm 1^{\circ} \mathrm{C}$ in a thermostatic water bath heater with continuous stirring of $100 \mathrm{rpm}$ for $15 \mathrm{~min}$. The slurry was out cooled to room temperature $\left(30 \pm 1^{\circ} \mathrm{C}\right)$ and incubation was continued for $36 \mathrm{~h}$. Sample were collected at $6 \mathrm{~h}$ interval and were subjected to reducing sugar and initial velocity determination. To study the inhibitory effect of cyanide on enzyme activity, cyanide with various concentration 50, 100 and $150 \mathrm{mg}$ cyanide/ $\mathrm{kg}$ of starch was added to the starch slurry. Samples were periodically withdrawn from the flask at $6 \mathrm{~h}$ interval and were substantially subjected to reducing sugar and kinetic parameters determinations. Prior to reducing sugar determination through Spectrophotometry, the samples were centrifuged (100rpm, $4^{\circ} \mathrm{C}$ and $10 \mathrm{~min}$ ) to obtain the clear filtrates.

\subsection{Analytical Methods for Determination of Reducing Sugar}

The reducing sugar was measured using dinitrosalicylic acid (DNS) method described by Miller [17]. Reagent consisting of aqueous solution of $1 \%$ DNS, $0.05 \%$ sodium sulfite, $20 \%$ potassium sodium tartrate tetrahydrate and $1 \%$ sodium hydroxide solution was added in the ratio $3: 1$ to the samples in the glass tubes, and followed by shaken and incubated them in a boiling water bath for $8 \mathrm{~min}$. Prior to measuring the absorbance at $540 \mathrm{~nm}$ by using a UV/visible spectrophotometer (UV-160A, SHIMADZU, Kyoto, Japan), the reacted samples were cooled in an ice water bath for $5 \mathrm{~min}$. Glucose solutions ( 0 to $10 \mathrm{~g} / \mathrm{L}$ ) were used as standard. Therefore, the reducing sugar concentrations obtained were reported as $\mathrm{g} / \mathrm{L}$.

\subsection{Determination of Kinetic Parameters}

In general, the Michaelis and Menten [15] equation has proven to be the simples yet a powerful approach to describe the kinetics of most enzymatic reaction, as shown below:

$v_{o}=\frac{V_{\max }[S]}{K_{m}+[S]}$

where $V_{o}$ is the initial reaction velocity, $[S]$ is the initial substrate concentration, $V_{\max }$ is the maximum rate of reaction at infinite substrate concentration, and $K_{m}$ is the Michaelis-Menten constant of the substrate. 
Cyanogenic inhibition can be characterized by end product inhibition and the enzyme kinetics using a set of linear plots, often of Lineweaver-Burk type [18]. This simplified approach in the kinetics experiments is to measure the initial reaction velocity, designated $V_{o}$. The amount of the product formed at different substrate concentration $\left[S_{o}\right]$ is plotted as a function of time. The initial reaction velocity $\left[V_{o}\right]$ for each substrate concentration is determined from the slope of the curve at beginning of the reaction [19]. The characteristic constants, namely $V_{\max }, K_{m}$ and $K_{i}$ can be determined experimentally by incubating the enzyme with different substrate concentrations. The results can be plotted as a graph of the initial reaction velocity, $V_{o}$ against the initial substrate concentration, $\left[S_{o}\right]$. When we plot of $1 /$ $V_{o}$ versus $1 /\left[S_{o}\right]$, a straight line should be obtained with the y intercept (for determining $V_{\max }$ ) and the $\mathrm{x}$ intercept (for determining $K_{m}$ ) [20-22]. The value of dissociation constant $\left(K_{i}\right)$ can be determined using the Dixon plot, where the slopes of the Lineweaver-Burk plots are plotted as function of inhibitor concentrations $[I]$. For this plot, the $\mathrm{x}$ intercept represents the value of $-K_{i}[23]$.

\subsection{Inhibitory Kinetic Analysis}

The noncompetitive inhibition mechanism can be described by the Lineweaver-Burk equation in double-reciprocal form and can be written as follow:

$\frac{1}{V}=\frac{K_{m}}{V_{\max }}\left[1+\frac{[I]}{K_{i}}\right] \frac{1}{[S]}+\frac{1}{V_{\max }}\left[1+\frac{[I]}{\alpha K_{i}}\right]$

and the secondary plot can be constructed as:

slope $=\frac{K_{m}}{V_{\max }}+\frac{K_{m}(I)}{V_{\max } K_{i}}$

$\mathrm{Y}$-intercept $=\frac{1}{V_{\max }}+\frac{1}{a K_{i} V_{\max }}$

where $V$ is the enzyme reaction rate in the absence and presence of cyanide. $K_{i}$ and $K_{m}$ are the inhibition constant and Michaelis-Menten constant respectively. $\alpha$ is the ratio of the uncompetitive inhibition constant to competitive inhibition constant, and the value of $\alpha$ is 1 as noncompetitive inhibition. $[I]$ and $[S]$ are the concentration of inhibitor and substrate, respectively. The secondary plot of slope versus $[I]$ are linearly fitted, assuming a single inhibition site [23].

\section{Result and Discussion}

\subsection{Effect of Cyanide on Reducing sugar}

The presence of cyanide at 50,100 and $150 \mathrm{mg} / \mathrm{kg}$, during enzymatic hydrolysis of starch at concentrations (100$400 \mathrm{~g} / \mathrm{L}$ ) for $36 \mathrm{~h}$, with concentration of enzyme $1.5 \%$ $(\mathrm{w} / \mathrm{w}), \mathrm{pH} 4$ and $30^{\circ} \mathrm{C}$ resulted in a significant decrease of reducing sugar concentration as shown in Table 1. It was observed that the reducing sugar concentration increased with increasing initial concentration native cassava starch. However, in addition of cyanide (50-150 mg cyanide $/ \mathrm{kg}$ ) into the slurry of various starch concentrations $(100-400 \mathrm{~g} / \mathrm{L})$ decreased the reducing sugar concentrations. This condition indicates that cyanide being possibly an enzyme inhibitor; therefore it needs to be proven further. Masiero et al. [24] studied the hydrolysis of fresh potato $(200 \mathrm{~g} / \mathrm{L})$ with Stargen ${ }^{\mathrm{TM}} 002\left(45 \mathrm{GAUg}^{-1}\right)$ for $62 \mathrm{~h}$. After the first $20 \mathrm{~h}$, the glucose concentration liberated was $30 \mathrm{~g} / \mathrm{L}$. Shanavas et al. [25] investigated a hydrolysis of cassava starch $(200 \mathrm{~g} / \mathrm{L})$, by $\operatorname{Stargen}^{\mathrm{TM}} 002$ with concentration $0.4 \%(\mathrm{w} / \mathrm{w})$ for $24 \mathrm{~h}$ at $30^{\circ} \mathrm{C}$. The reducing sugar concentration obtained was $185 \mathrm{~g} / \mathrm{L}$. Although, the same substrate concentration of $200 \mathrm{~g} / \mathrm{L}$ and same enzyme were used in this research and other research groups, different glucose and reducing sugar concentrations were obtained during hydrolysis of starch. This phenomenon can be attribuded to the difference in enzyme activity, enzyme concentration, reaction time and type of starch.

\subsection{Effect of initial native cassava starch and cyanide concentrations on initial reaction velocity}

Effect of the addition of cyanide at concentration (50$150 \mathrm{mg} / \mathrm{kg}$ ) on the initial reaction velocity of enzyme was investigated. As shown in Fig. 1, the initial reaction velocity increases with the increase of substrate concentration to some extent. However, further increase in substrate concentration may cause saturation kinetics. Therefore, addition more substrate under this condition would not change the initial reaction velocity. Hence the slope of the plot of initial reaction velocity, $V_{o}$ versus $\left[S_{o}\right]$ would approach zero.

A simple visualization of the enzyme-catalyzed reaction scheme is given in Fig. 2 [26]. At concentration of cassava starch $\left[S_{o}\right]$ up to $100 \mathrm{~g} / \mathrm{L}$ the concentration of ES would be directly proportional to $\left[S_{o}\right]$. Hence, the velocity would depend on $\left[S_{o}\right]$. At very high concentration of $S$, practically all of the enzyme would be present in the form of the ES complex. 
Table 1 The reducing sugar concentrations obtained from enzymatic hydrolysis of cassava starch with and without addition of cyanide

\begin{tabular}{lcc}
\hline Cassava starch & Reducing sugar, $\mathrm{g} / \mathrm{L}$ & Reduction of reducing sugar, $\%$ \\
\hline NCS $100 \mathrm{~g} / \mathrm{L}$ & 51.74 & 5.18 \\
NCS $100 \mathrm{~g} / \mathrm{L}+50 \mathrm{mg}$ cyanide $/ \mathrm{kg}$ & 49.06 & 10.69 \\
NCS $100 \mathrm{~g} / \mathrm{L}+100 \mathrm{mg}$ cyanide $/ \mathrm{kg}$ & 46.21 & 18.82 \\
NCS $100 \mathrm{~g} / \mathrm{L}+150 \mathrm{mg}$ cyanide $/ \mathrm{kg}$ & 42.01 & - \\
NCS $200 \mathrm{~g} / \mathrm{L}$ & 59.4 & 6.06 \\
NCS $200 \mathrm{~g} / \mathrm{L}+50 \mathrm{mg}$ cyanide $/ \mathrm{kg}$ & 55.8 & 11.45 \\
NCS $200 \mathrm{~g} / \mathrm{L}+100 \mathrm{mg}$ cyanide $/ \mathrm{kg}$ & 52.6 & 15.66 \\
NCS $200 \mathrm{~g} / \mathrm{L}+150 \mathrm{mg}$ cyanide $/ \mathrm{kg}$ & 50.1 & - \\
NCS $300 \mathrm{~g} / \mathrm{L}$ & 69.11 & 7.22 \\
NCS $300 \mathrm{~g} / \mathrm{L}+50 \mathrm{mg}$ cyanide/kg & 64.12 & 11.22 \\
NCS $300 \mathrm{~g} / \mathrm{L}+100 \mathrm{mg}$ cyanide $/ \mathrm{kg}$ & 61.35 & 15.45 \\
NCS $300 \mathrm{~g} / \mathrm{L}+150 \mathrm{mg}$ cyanide $/ \mathrm{kg}$ & 58.43 & - \\
NCS $400 \mathrm{~g} / \mathrm{L}$ & 69.56 & 5.15 \\
NCS $400 \mathrm{~g} / \mathrm{L}+50 \mathrm{mg}$ cyanide/kg & 65.98 & 11.89 \\
NCS $400 \mathrm{~g} / \mathrm{L}+100 \mathrm{mg}$ cyanide/kg & 61.29 & 19.18 \\
NCS $400 \mathrm{~g} / \mathrm{L}+150 \mathrm{mg}$ cyanide/kg & 56.22 & \\
\hline
\end{tabular}

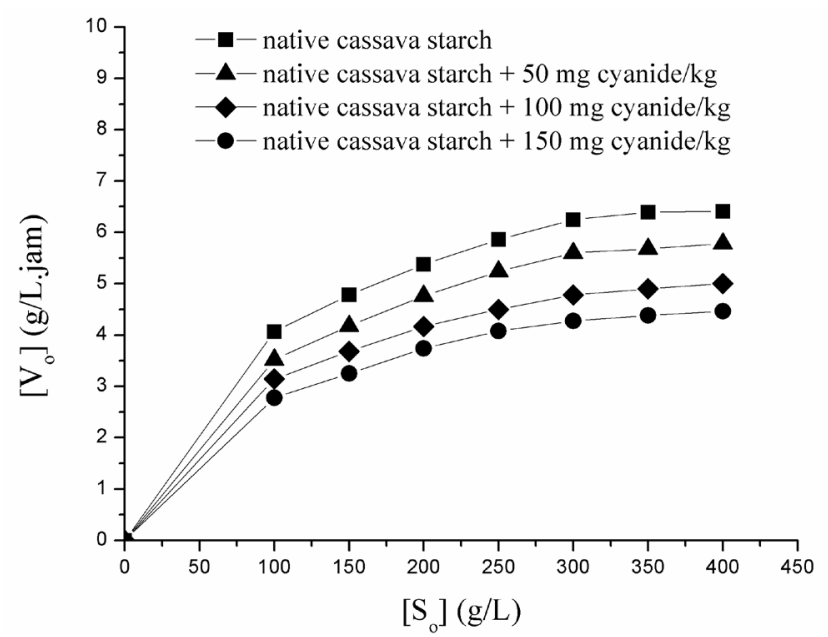

Fig. 1 Effect of native cassava starch with and without the presence of cyanide at various concentrations $(50-150 \mathrm{mg} / \mathrm{kg})$ at $\mathrm{pH} 4$ and $30^{\circ} \mathrm{C}$.

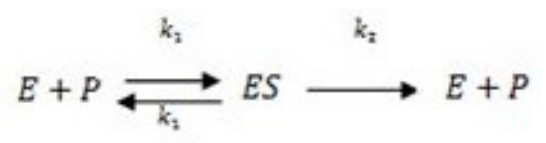

Fig. 2 Enzyme-catalyzed reaction

Dhital et al. [24] studied the inhibition of $\alpha$-amylase activity by cellulose. They hydrolyzed maize starch at concentrations of 5 to $40 \mathrm{mg} / \mathrm{mL}$ using $\alpha$-amylase with the presence of 0 to $30 \mathrm{mg} / \mathrm{mL}$ of cellulose. The $V_{\max }$ values in the absence of cellulose were $0.125 \mathrm{mM} / \mathrm{min}$. On the other hand, the values of $V_{\max }$ with the presence of
5 to $30 \mathrm{mg} / \mathrm{mL}$ of cellulose were ranged from 0.009 to $0.036 \mathrm{mM} / \mathrm{min}$. This finding clearly indicates that cellulose does indeed inhibit $\alpha$-amylase activity over the range of concentration studied. This finding clearly indicates that cellulose does indeed inhibit $\alpha$-amylase activity over the range of concentration studied.

At a given reaction time, the concentrations of reducing sugar produced from hydrolysis of native cassava starch without the presence of cyanide were higher than that of with cyanide. This observation indicates higher hydrolysis rate of native cassava starch without the presence of cyanide as compared to that with cyanide. Therefore, we recommend to prefer the use of free cyanide cassava starch in enzymatic hydrolysis instead of those with considerable cyanide content, so that the concentration of reducing sugar obtained can be higher.

\subsection{Determination of Kinetic Parameters}

The mode of kinetic inhibition of the cyanide was determined by Lineweaver-Burk plot. The plot of $1 / V_{o}$ versus $1 /\left[S_{o}\right]$ yields a linear line with a slope of $K_{m} / V_{\max }$ and intercept of $1 / V_{\max }$ as shown in Fig. 3.

The results show that double reciprocal plots straight lines were intercepted at single point in the second quadrant. This plot clearly indicated the pattern of the noncompetitive inhibition. Table 2 summarizes the comparison of the maximum reaction velocity $\left(V_{\max }\right)$ and the saturation 
- native cassava starch

- native cassava starch $+50 \mathrm{mg}$ cyanide/kg

- native cassava starch $+100 \mathrm{mg}$ cyanide $/ \mathrm{kg}$

- native cassava starch $+100 \mathrm{mg}$ cyanide $/ \mathrm{kg}$

- native cassava starch $+150 \mathrm{mg}$ cyanide $/ \mathrm{kg}$

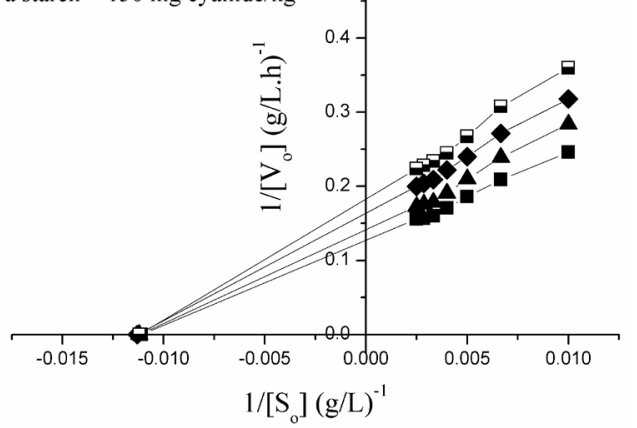

Fig. 3 Lineweaver-Burk plots for native cassava starch with and without presence of cyanide at various concentrations $(50-150 \mathrm{mg} / \mathrm{kg})$ at $\mathrm{pH} 4$ and $30^{\circ} \mathrm{C}$.

constants $\left(K_{m}\right)$ obtained in hydrolysis of native cassava starch and native cassava starch added with cyanide at various concentrations $(50-150 \mathrm{mg} / \mathrm{kg})$ at $\mathrm{pH} 4$ and $30^{\circ} \mathrm{C}$. Subsequently, the inhibitor constant, $K_{i}$ was found to be $0.33 \mathrm{mg} / \mathrm{L}$, as shown in Fig 4. This result is well suited to the noncompetitive inhibition model shown in Fig. 5. The S and I are not mutually exclusive, but EIS is catalytically inactive. When $\mathrm{S}$ binds, the enzyme undergoes a conformational change with aligns the catalytic centre, with the susceptible bond of S; I interferes with the conformational change, but no effect on S binding. Adam [27] also reported cyanide, probably in the undissociated form to be competitive inhibitor for green bean lipoxygenase with inhibitor constant $K_{i}=1.54 \times 10^{-3} \mathrm{M} \mathrm{KCN}$.

Zołnierowicz et al. [28] studied the effect of $\mathrm{KCN}$ of mitochondrial malic enzyme from human placenta. The study showed that $\mathrm{KCN}$ is an uncompetitive inhibitor of this enzyme. In contradiction to the mitochondrial enzyme, the cytosolic malic enzymes from other sources were only slightly affected by $\mathrm{KCN}$ and under the same conditions the effect of azide was negligible. Dhital et al. [29] investigated the $\alpha$-amylase hydrolysis of maize starch in the presence of cellulose. They found that the inhibition is a mixed mode inhibition or non-competitive inhibition. The dissociation constant for EIS complex obtained in their study was $6 \mathrm{mg} / \mathrm{mL}$.

Recently, Hargono et al. [8] investigated the kinetics of the enzymatic hydrolysis of sweet cassava starch and bitter cassava and gadung (Dioscorea hispida Dennst) flours using GSHE at low temperature. The Michaelis-Menten constant $\left(K_{m}\right)$ for these three substrates were 137.74, 141.64 and $140.84 \mathrm{~g} / \mathrm{L}$, respectively. Based on the inhibition type
Table 2 Comparison of the maximum velocity $\left(V_{\max }\right)$ and the saturation constants $\left(K_{m}\right)$

\begin{tabular}{lcc}
\hline Substrate & $V_{\max }(\mathrm{g} / \mathrm{L} \cdot \mathrm{h})$ & $K_{m}(\mathrm{~g} / \mathrm{L})$ \\
\hline NCS & 7.87 & 91.13 \\
NCS + 50 mg cyanide/kg & 6.90 & 91.42 \\
NCS+100 mg cyanide/kg & 6.02 & 90.54 \\
NCS+150 mg cyanide/kg & 5.44 & 91.68 \\
\hline
\end{tabular}

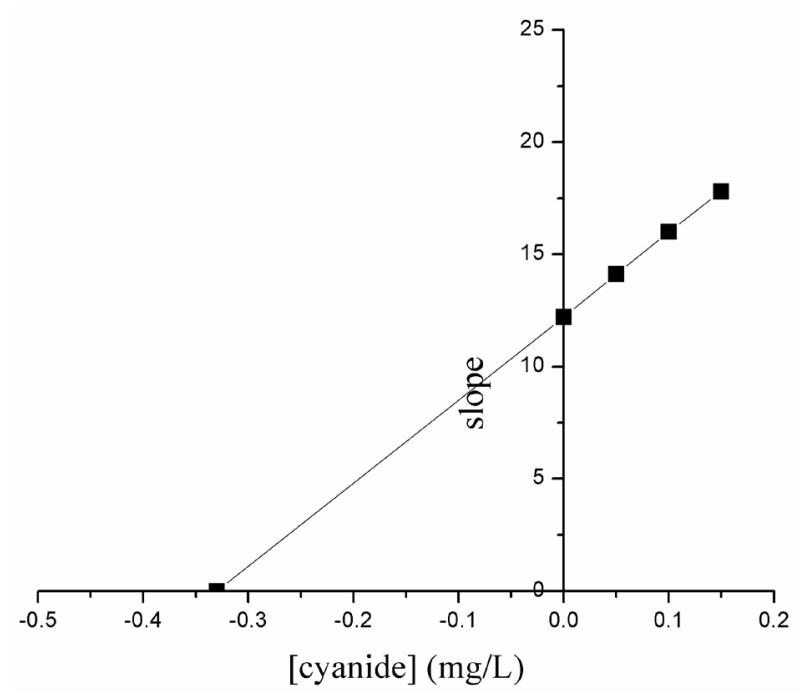

Fig. 4 The plot for the determination of the inhibitor constant for noncompetitive inhibition

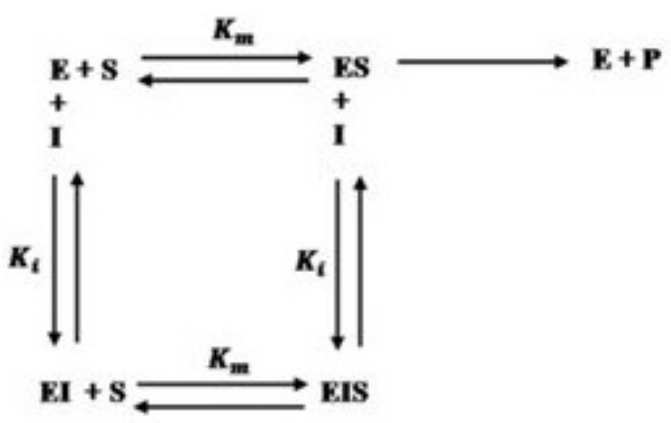

Fig. 5 Type of noncompetitive inhibition

analysis, the effect of cyanide in the sweet cassava starch, bitter cassava and gadung flours enzymatic hydrolysis can be classified as a noncompetitive inhibition.

\section{Conclusion}

Based on the experimental and modeling results, it is clearly shown that cyanide gives an inhibitory effect on the enzymatic hydrolysis of cassava starch using GSHE. Addition of cyanide (50-150 mg cyanide/ $\mathrm{kg}$ ) during hydrolysis of native cassava starch decreased the $V_{\max }$ values significantly. However, addition of cyanide did not significantly change the Michaelis-Menten constants $\left(K_{m}\right)$ of 
the system. Based on the Lineweaver-Burk plot for native cassava starch at various concentrations $(100-400 \mathrm{~g} / \mathrm{L})$ and the effect of cyanide concentrations $(50-150 \mathrm{mg} / \mathrm{kg})$,

\section{References}

[1] Moshi, A. P., Crespo, C. F., Badshah, M., Hosea, K. M. M., Mshandete, A. M. "Characterisation and evaluation of a novel feedstock, Manihot glaziovii, Muell. Arg, for production of bioenergy carriers: Bioethanol and biogas", Bioresource Technology, 172 , pp. 58-67, 2014.

https://doi.org/10.1016/j.biortech.2014.08.084

[2] Moshi, A. P., Crespo, C. F., Badshah, M., Hosea, K. M. M., Mshandete, A. M., Mattiasson, B. "High bioethanol titre from Manihot glaziovii through fed-batch simultaneous saccharification and fermentation in Automatic Gas Potential Test System", Bioresource Technology, 156, pp. 348-356, 2014.

https://doi.org/10.1016/j.biortech.2013.12.082

[3] Cock, J. H. "Cassava: New Potential for a Neglected Crop", Westview Press, Boulder and London, Colorado, 1985.

[4] Cereda, M. "Linamarin: the toxic compound of cassava", Journal of Venomous Animals and Toxins, 2(1), pp. 6-12, 1996. https://doi.org/10.1590/S0104-79301996000100002

[5] Elias, M., Mühlen, G. S., McKey, D., Roa, A. C., Tohme, J. "Genetic diversity of traditional South American landraces of cassava (Manihot esculenta Crantz): an analysis using microsatellites", Economic Botany, 58(2), pp. 242-256, 2004.

https://doi.org/10.1663/0013-0001(2004)058[0242:GDOT$\mathrm{SA}] 2.0 . \mathrm{CO} ; 2$

[6] Lambri, M., Fumi, M. D., Roda, A., de Faveri, D. M. "Improved processing methods to reduce the total cyanide content of cassava roots from Burundi", African Journal of Biotechnology, 12(19), pp. 2685-2691. 2013.

https://doi.org/10.5897/AJB2012.2989

[7] Djazuli, M., Bradbury, J. H. "Cyanogen content of cassava roots and flour in Indonesia", Food Chemistry, 65(4), pp. 523-525, 1999. https://doi.org/10.1016/S0308-8146(98)00218-0

[8] Hargono, H., Jos, B., Kumoro, A. C. "Kinetics of the enzymatic hydrolysis of sweet cassava starch and bitter cassava flour and gadung (Dioscorea hispida Dennst) flour at low temperature", Bulletin of Chemical Reaction Engineering \& Catalysis, 12(2), pp. 256-262, 2017.

https://doi.org/10.9767/bcrec.12.2.808.256-262

[9] Tung, T. Q., Miyata, N., Iwahori, K. "Selection of filamentous fungi for treatment of synthetic cassava starch processing wastewater containing cyanide", Japanese Journal of Water Treatment Biology, 39, pp. 109-117, 2003.

https://doi.org/10.2521/jswtb.39.109

[10] Kavasoglu, M., Sarioglu, Y., Uysal, K., Donmez, M., Altikat, S., Yetek, I., Kuru, H. I. "Effect of sodium cyanide on antioxidant enzyme activities and lipid peroxidation in some tissues of mirror carp (Cyprinus carpio)", Pakistan Journal of Zoology, 47, pp. 1777-1782. 2015.

https://doi.org/10.1007/s11356-014-2896-6 the cyanide inhibits the cassava starch hydrolysis according to a non-competitive inhibition, with the $K_{i}$ value was $0.33 \mathrm{mg} / \mathrm{L}$.

[11] Shariffa, Y. N., Karim, A. A., Fazilah, A., Zaidul, I. S. M. "Enzymatic hydrolysis of granular native and mildly heat-treated tapioca and sweet potato starches at sub gelatinization temperature", Food Hydrocolloid, 23(2), pp. 434-440. 2009. https://doi.org/10.1016/j.foodhyd.2008.03.009

[12] Johnsons, R., Padmaja, G., Moorthy, S. N. "Comparative production of glucose and high fructose syrup from cassava and sweet potato roots by direct conversion techniques", Innovative Food Science \& Emerging Technologies, 10, pp. 616-620, 2009. https://doi.org/10.1016/j.ifset.2009.04.001

[13] Johnsons, R., Padmaja, G. "Comparative studies on the production of glucose and high fructose syrup from tuber starches", International Research Journal of Biological Science, 2(10), pp. 68-75. 2013. [online] Available at: https://pdfs.semanticscholar.org/f851/ea804c93dba077b6e5375e061a827c51c091.pdf [Accessed: 26 October 2017]

[14] Uthumporn, U., Zaidul, I. S. M., Karim, A. A. "Hydrolysis of granular starch at sub-gelatinization temperature using a mixture of amylolytic enzymes", Food and Bioproducts Processing, 88(1), pp. 47-54. 2010.

https://doi.org/10.1016/j.fbp.2009.10.001

[15] Michaelis, L., Menten, M. L. "Die Kinetik der Invertinwirkung" (The Kinetics of Invertase Action), Biochemistry Zeitung, 49, pp. 333-369, 1913. [online] Available at: http://path.upmc.edu/ divisions/chp/PDF/Michaelis-Menten_Kinetik.pdf [Accessed: 06 November 2017]

[16] Genencor. STARGEN"T 002. "Granular starch hydrolyzing enzyme for ethanol production", 2009.

[17] Miller, G. L. "Use of dinitrosalycilic acid reagent for determination reducing sugar", Analytical Chemistry, 31(3), pp. 426-428, 1959. https://doi.org/10.1021/ac60147a030

[18] Lineweaver, H., Burk, D. "The determination of enzyme dissociation constants", Journal of the American Chemical Society, 56(3), pp. 658-666, 1934.

https://doi.org/10.1021/ja01318a036

[19] Lehninger, A. L. "Principles of Biochemistry", 5th ed., W.H. Freeman, New York, 2008.

https://doi.org/10.1002/bmb.2005.494033010419

[20] Fange, D., Lovmar, M., Michael, Y., Ehrenberg, M. "Identification of enzyme inhibitory mechanisms from steady-state kinetics", Biochimie, 93(9), pp. 1623-1629, 2011. https://doi.org/10.1016/j.biochi.2011.05.031

[21] Kim, J. K., Jung, Y. J., Lee, S. H., Lee, H., Kim, J. C. "Kinetic analysis and enzyme concentration effect relevant to dependence of amylolysis of starch granules on specific surface area concentration", Food Science Biotechnology, 23(2), pp. 475-481, 2014. https://doi.org/10.1007/s10068-014-0065-9 
[22] Yoshino, M., Murakami, K. "A graphical method for determining inhibition constants", Journal of Enzyme Inhibition and Medicinal Chemistry, 24(6), pp. 1288-1290, 2009. https://doi.org/10.3109/14756360902829766

[23] Yan, J., Zhang, G., Pan, J., Wang, Y. " $\alpha$-Glucosidase inhibition by luteolin, kinetics, interaction and molecular docking", International Journal of Biology Macromolecule, 64, pp. 213-223, 2014. https://doi.org/10.1016/j.ijbiomac.2013.12.007

[24] Masiero, S. S., Peretti, A., Trierweiler, L.F., Trierweiler, J. O. "Simultaneous cold hydrolysis and fermentation of fresh sweet potato", Biomass and Bioenergy, 70, pp. 174-183, 2014. https://doi.org/10.1016/j.biombioe.2014.08.007

[25] Shanavas, S., Padmaja, G., Moorthy, S. N., Sajeev, M. S., Sheriff, J. T. "Process optimization for bioethanol production from cassava sarch using novel eco-friendly enzymes", Biomass and Bioenergy, 35(2), pp. 901-909, 2010.

https://doi.org/10.1016/j.biombioe.2010.11.004
[26] Copeland, R. A. "Enzymes: Practical introduction to structure, mechanism, and data analysis", 2nd ed., John Wiley \& Sons, Inc., New York, 2002.

[27] Adams, J. B. "Inhibition of green bean lipoxygenase by cyanide", Food Chemistry, 31, pp. 243-250, 1989. https://doi.org/10.1016/0308-8146(89)90065-4

[28] Zolnierowicz, S., Zelewski, M., Swierczyn, J., Zelewski, L. "Cyanide-an competitive inhibitor of NAD(P)-dependent maliz enzyme from human term placental mitochondria", Biochemistry International, 17, pp. 303-309, 1988.

[29] Dhital, S., Gidley, M. J., Warren, J. "Inhibition of $\alpha$-amylase activity by cellulose: kinetic analysis and nutritional implications", Carbohydrate Polymer, 123, pp. 305-312, 2015. https://doi.org/10.1016/j.carbpol.2015.01.039 